\title{
AN ANALYSIS OF TOP MBA IN INFORMATION SYSTEMS PROGRAMS
}

\author{
Chen-Huei Chou, College of Charleston, chouc@cofc.edu
}

\begin{abstract}
Information Systems is an ever-changing field that requires constant updates. In order for university curricula to reflect changes in the field, it is of great importance to understand the key topics being covered by the Information Systems programs. Not only do the education providers need to know the current trends in the field but also the education receivers. In this paper, top $10 \mathrm{MBA}$ in Information Systems programs are analyzed using grounded theory. In total, 169 courses were collected from the programs and classified into managerially oriented and technically oriented groups. In sum, 54 unique managerial courses were found and 42 unique technical courses were identified. Information Systems Strategy and Supply Chain Management are the most commonly covered managerial courses, while Data Mining is the most commonly offered technical course. Based on the coverage of courses, the University of Texas at Austin stands out among the 10 programs. The University of Pennsylvania has the strongest emphasis on managerially oriented IS courses, while Carnegie Mellon University has the strongest focus on Information Systems technology.
\end{abstract}

Keywords: Information Systems Curriculum, Grounded Theory, Managerially Oriented Course, Technically Oriented Course.

\section{INTRODUCTION}

New technologies related to information systems become available every year. The adoption of these technologies and their alignment with core business objectives are major tasks being undertaken by enterprises. Management with relevant knowledge can help businesses efficiently handle the changes that occur. Knowledge offered by an MBA in Information Systems (IS) should promote this objective. According to U.S. News and World Reports, "An M.B.A. in information systems helps students grasp the technical side of business administration. Coursework focuses on working with computers, networks, and IT systems." [20] In order to better emphasize the information systems aspect of an MBA program, many universities offer specialization, concentration, emphasis, and a special track in the field of information systems. However, different universities have different requirements for their concentration in Information Systems. Most of the top 10 MBA in IS programs [19] specify clear requirements (around three to six relevant elective courses), while there are still a few programs that do not have specific requirements. For example, the Massachusetts Institute of Technology, which has a top ranked MBA in IS program, offers classes in an ISrelated field-Information Technology, and provides a personalized curriculum that allows students the flexibility to prepare their career with a mix of coursework in various fields. There is no required number of hours nor coursework for the completion of IS courses. Table 1 summarizes the program details of the top $10 \mathrm{MBA}$ in IS programs along with their mission statements. The ranking is based on the latest 2013 results published by U.S. News and World Reports [19].

Table 1. Program Details of Top 10 MBA in IS Programs

\begin{tabular}{|l|l|l|l|}
\hline $\begin{array}{l}\text { University Name } \\
\text { and Ranking }\end{array}$ & $\begin{array}{l}\text { Field of } \\
\text { Specialization }\end{array}$ & $\begin{array}{l}\text { Concentration } \\
\text { Requirements }\end{array}$ & Mission Statement* \\
\hline 01-Massachusetts & $\begin{array}{l}144 \text { units of } \\
\text { electives }\end{array}$ & N/A & N/A \\
Institute of \\
$\begin{array}{l}\text { Technology } \\
\text { (Sloan) }\end{array}$
\end{tabular}




\section{Issues in Information Systems}

Volume 13, Issue 1, pp. 123-130, 2012

\begin{tabular}{|c|c|c|c|}
\hline \multirow[t]{2}{*}{$\begin{array}{l}\text { 02-Carnegie } \\
\text { Mellon University } \\
\text { (Tepper) }\end{array}$} & $\begin{array}{l}\text { Technology } \\
\text { Leadership } \\
\text { track }\end{array}$ & $\begin{array}{l}18 \text { units of } \\
\text { technology or } \\
\text { entrepreneurship- } \\
\text { centric courses }\end{array}$ & $\begin{array}{l}\text { Computing technologies have become pervasive and } \\
\text { fundamental to the operation of modern businesses. } \\
\text { They are at the core of today's knowledge-based } \\
\text { economy, fueling the development of innovative } \\
\text { products, services and business processes. Developing } \\
\text { great software-intensive products and services, } \\
\text { however, requires more than just technical excellence. } \\
\text { Technology leaders also need a deep understanding of } \\
\text { business fundamentals and of how to weave novel } \\
\text { technologies, business processes and market forces } \\
\text { together to create successful products and services. [2] }\end{array}$ \\
\hline & $\begin{array}{l}\text { Information } \\
\text { Systems } \\
\text { concentration }\end{array}$ & $\begin{array}{l}\text { 3-4 elective } \\
\text { courses }\end{array}$ & $\begin{array}{l}\text { The unprecedented speed in which technology } \\
\text { transforms markets and economies has altered the way } \\
\text { multi-national organizations successfully compete. As } \\
\text { the university that is synonymous with technology, it } \\
\text { has been a key player in leading this trend. Our } \\
\text { students represent a new breed of leader, one who } \\
\text { understands global issues and is able to take advantage } \\
\text { of emerging trends and technologies. } \\
\text { Broadly encompassing an array of technical and } \\
\text { managerial coursework as well as applied project } \\
\text { experience, the Information Technology concentration } \\
\text { is aimed at preparing students for a career in a } \\
\text { technology-related field. [1] }\end{array}$ \\
\hline $\begin{array}{l}\text { 03-University of } \\
\text { Minnesota } \\
\text { (Carlson) }\end{array}$ & $\begin{array}{l}\text { Information } \\
\text { Systems }\end{array}$ & 10 credits & $\begin{array}{l}\text { An emphasis in information systems provides students } \\
\text { with the ability to lead in the digital age. Students } \\
\text { taking this emphasis will appreciate the profound and } \\
\text { often disruptive impact information and } \\
\text { communication technologies have on business and } \\
\text { society. Students will garner the necessary skills to } \\
\text { leverage IT to create efficient organizations } \\
\text { characterized by standardized business processes and } \\
\text { integrated data. Additionally, the emphasis will prepare } \\
\text { students for an increasingly compliance and security } \\
\text { intensive environments due to heavy integration of IT } \\
\text { with key financial and accounting processes. Finally, } \\
\text { they will learn how to innovate and create top-line } \\
\text { growth and differentiation opportunities based on data- } \\
\text { driven business intelligence, harnessing social media to } \\
\text { develop customer intimacy and by optimally } \\
\text { leveraging a global sourcing of IT and IT enabled } \\
\text { business processes. [16] }\end{array}$ \\
\hline $\begin{array}{l}\text { 04-University of } \\
\text { Texas at Austin } \\
\text { (McCombs) }\end{array}$ & $\begin{array}{l}\text { Information } \\
\text { Management }\end{array}$ & $\begin{array}{l}1 \text { required } \\
\text { (Information } \\
\text { Technology } \\
\text { Management) } \\
3 \text { elective } \\
\text { courses }\end{array}$ & $\begin{array}{l}\text { The Texas MBA Information Management (IM) } \\
\text { concentration focuses on developing business leaders } \\
\text { who understand (1) how to leverage IT to create value } \\
\text { for customers using improved business processes and } \\
\text { innovative information design; (2) the strategic, } \\
\text { financial and economic implications of IT projects. } \\
\text { The concentration provides a strong foundation so that } \\
\text { students can articulate the strategic and business value } \\
\text { of IT beyond an IT-centric view and develop the } \\
\text { expertise required to manage global resources and }\end{array}$ \\
\hline
\end{tabular}




\section{Issues in Information Systems}

Volume 13, Issue 1, pp. 123-130, 2012

\begin{tabular}{|c|c|c|c|}
\hline & & & $\begin{array}{l}\text { projects enabled through IT. Finally, the concentration } \\
\text { strives to provide an environment for students to } \\
\text { develop entrepreneurial thinking and leadership skills } \\
\text { through activities such as extracurricular case } \\
\text { competition and projects for local organizations. [18] }\end{array}$ \\
\hline $\begin{array}{l}\text { 05-University of } \\
\text { Arizona (Eller) }\end{array}$ & $\begin{array}{l}\text { Management } \\
\text { Information } \\
\text { Systems }\end{array}$ & $\begin{array}{l}4 \text { elective } \\
\text { courses }\end{array}$ & $\begin{array}{l}\text { Management information systems (MIS) is the design } \\
\text { and management of information technology (IT) for an } \\
\text { organization. It focuses on the best way to enable the } \\
\text { organization to meet its goals and business challenges. } \\
\text { MIS professionals are the "communication bridges" } \\
\text { between IT and the business community. They analyze, } \\
\text { design, implement, and manage IT strategy to help } \\
\text { solve business problems. [14] }\end{array}$ \\
\hline $\begin{array}{l}\text { 06-University of } \\
\text { Maryland (Smith) }\end{array}$ & $\begin{array}{l}\text { Information } \\
\text { Systems }\end{array}$ & & $\begin{array}{l}\text { Information systems and technologies are fueling the } \\
\text { transformation of corporations to meet the challenges } \\
\text { of the knowledge-based economy. Smith offers a rich } \\
\text { selection of courses in this area to prepare students for } \\
\text { careers in the management, design, and } \\
\text { implementation of information systems. [15] }\end{array}$ \\
\hline $\begin{array}{l}\text { 07- University of } \\
\text { Pennsylvania } \\
\text { (Wharton) }\end{array}$ & $\begin{array}{l}\text { Information } \\
\text { Systems track }\end{array}$ & $\begin{array}{l}5 \text { elective } \\
\text { courses }\end{array}$ & $\begin{array}{l}\text { This major is relevant for those involved in the supply } \\
\text { chain of a business, whether it be with a physical } \\
\text { supply chain or an information-based system at the } \\
\text { retail or manufacturing end. The automotive and } \\
\text { transportation industries are good examples of } \\
\text { increasingly complex business areas that benefit from } \\
\text { the skills developed in this major. Individuals studying } \\
\text { Operations and Information Management may also } \\
\text { find attractive opportunities in management consulting } \\
\text { and private equity firms. [17] }\end{array}$ \\
\hline $\begin{array}{l}\text { 08-Stanford } \\
\text { University }\end{array}$ & $\begin{array}{l}\text { Up to } 18 \\
\text { electives }\end{array}$ & N/A & N/A \\
\hline $\begin{array}{l}\text { 09-Georgia State } \\
\text { University } \\
\text { (Robinson) }\end{array}$ & $\begin{array}{l}\text { Information } \\
\text { Systems }\end{array}$ & $\begin{array}{l}12 \text { hours for } \\
\text { concentration } \\
\text { or } \\
18 \text { hours for } \\
\text { major }\end{array}$ & $\begin{array}{l}\text { This concentration is intended to prepare students for } \\
\text { executive careers in management of information } \\
\text { systems functions, management of organizations that } \\
\text { involve intensive use of information technology, or a } \\
\text { career in consulting that builds on expertise in the } \\
\text { information systems area. [3] }\end{array}$ \\
\hline $\begin{array}{l}\text { 10-New York } \\
\text { University (Stern) }\end{array}$ & $\begin{array}{l}\text { Management } \\
\text { of } \\
\text { Information } \\
\text { Technology } \\
\text { and } \\
\text { Operations }\end{array}$ & 9 credit hours & $\begin{array}{l}\text { A specialization in Management of Information } \\
\text { Technology and Operations provides students with an } \\
\text { overview of management and its strategic alignment } \\
\text { with business models that are essential to achieving } \\
\text { business success. Operational excellence is the key } \\
\text { driver to performance in a world that is increasingly } \\
\text { driven by information. A specialization in Management } \\
\text { of Technology and Operations enables you to think } \\
\text { about technology-enabled business models and the } \\
\text { alignment of IT and Operations with corporate } \\
\text { strategy. [9] }\end{array}$ \\
\hline
\end{tabular}

* The mission statements are directly gathered from the programs' websites.

Based on the requirements of the top ranked MBA in IS programs, students pursuing the degree need only three to six elective courses in order to be professionals in the field. A careful selection of courses/program is crucial. 


\section{Issues in Information Systems}

Volume 13, Issue 1, pp. 123-130, 2012

According to the guidelines for graduate degree programs in Information Systems (i.e., master's of science in IS) suggested by Gorgone et. al [5], it is recommended to model the IS graduate degree programs with IS technology courses and IS management courses. The IS technology courses focus on four fields: 1) IT Infrastructure; 2) Analysis, Modeling, and Design; 3) Enterprise Models; and 4) Emerging Technologies and Issues. In addition, the IS management courses emphasize: 1) Project and Change Management, 2) Policy and Strategy, and 3) Integrated Capstone. All courses except the integrated capstone course are applicable to MBA in IS programs.

In the design of an IS curriculum, Topi et al. [12] suggest program guidelines for undergraduate degree programs in IS. Seven core courses are identified: 1) Foundations of Information Systems, 2) Data and Information Management, 3) Enterprise Architecture, 4) IT Infrastructure, 5) IS Project Management, 6) Systems Analysis and Design, and 7) IS Strategy, Management, and Acquisition. For IS master's level programs, Topi et al. [13] suggest that "IS as a field and master's programs in IS should consider reaching beyond the traditional business disciplines and beyond business as the domain context of the degree." They also discuss a successful program offered by the University of San Francisco that integrates biotechnology and information security.

In a related field - software management, a managerial direction of Information Technology, Shoemaker et al. [11] suggest including the following core courses: 1) Project Management, 2) Object Oriented Programming, 3) Software Requirements Specification, 4) Software Quality Assurance and Testing, and 5) Strategic Software Process Management. Managerial and technical courses are equally important in this curriculum design. In the curriculum design of IT-related engineering-oriented programs such as a master's of software assurance [8] and graduate software engineering [10], which are normally not offered by schools of business/management, courses with managerial aspects are not the major concern. Other than the design of curriculum of IS programs, Harder and Harper [6] propose a framework to assess MIS undergraduate programs and MIS student outcomes. The framework assesses four competency areas: technical, analytical, communicative, and managerial clusters.

Summarizing from prior studies, it is crucial to emphasize the managerial and technical aspects of IS education. Previous research focused on the undergraduate and graduate level (master's of science) of IS and related fields. However, there are no guidelines or suggestions for MBA in IS programs. Little is known about the orientation of the programs as well as the key courses being offered in this ever-changing field. Thus, this study strives to answer the following research questions:

- Which top ranked MBA in IS programs are managerially oriented?

- Which top ranked MBA in IS programs are technically oriented?

- What is the most commonly offered managerial course in the top ranked MBA in IS programs?

- What is the most commonly offered technical course in the top ranked MBA in IS programs?

- What is the top ranked MBA in IS program with the best coverage of IS courses?

- What is the top ranked MBA in IS program with the best coverage of managerial courses?

- What is the top ranked MBA in IS program with the best coverage of technical courses?

The rest of the paper is organized as follows. First, we discuss the methodology of the study, covering the processes of data collection and data analysis approach. Next, the results of the analysis are presented and discussed. Finally, the conclusions and future directions of the study are provided.

\section{RESEARCH METHODOLOGY}

In order to answer the above-mentioned research questions, this study focuses on a course analysis of the top 10 MBA in IS programs. In this section, the processes of data collection and methods of data analysis are discussed. 


\section{Issues in Information Systems}

Volume 13, Issue 1, pp. 123-130, 2012

\section{Data Collection}

The top 10 programs were identified based on the latest 2013 ranking of MBA in IS programs [19]. The courses designed as electives for concentration in IS were used. The course titles and course descriptions were collected individually from the 10 programs' official websites or graduate catalogs. We collected 169 courses from the 10 programs and further categorized them into managerially oriented and technically oriented groups as suggested by Gorgone et. al [5].

\section{Data Analysis Approach}

Since the courses covering similar topics may have different names, grounded theory [4] is applied to consistently compare and contrast the course titles and descriptions from different institutions. Grounded theory is "the discovery of theory from data" [4, p.1]. It involves an iterative process between data collection and analysis through comparing and contrasting findings at each stage with those of the next. The following proposed algorithm (Figure 1) describes the details of grounded theory applied in this study:

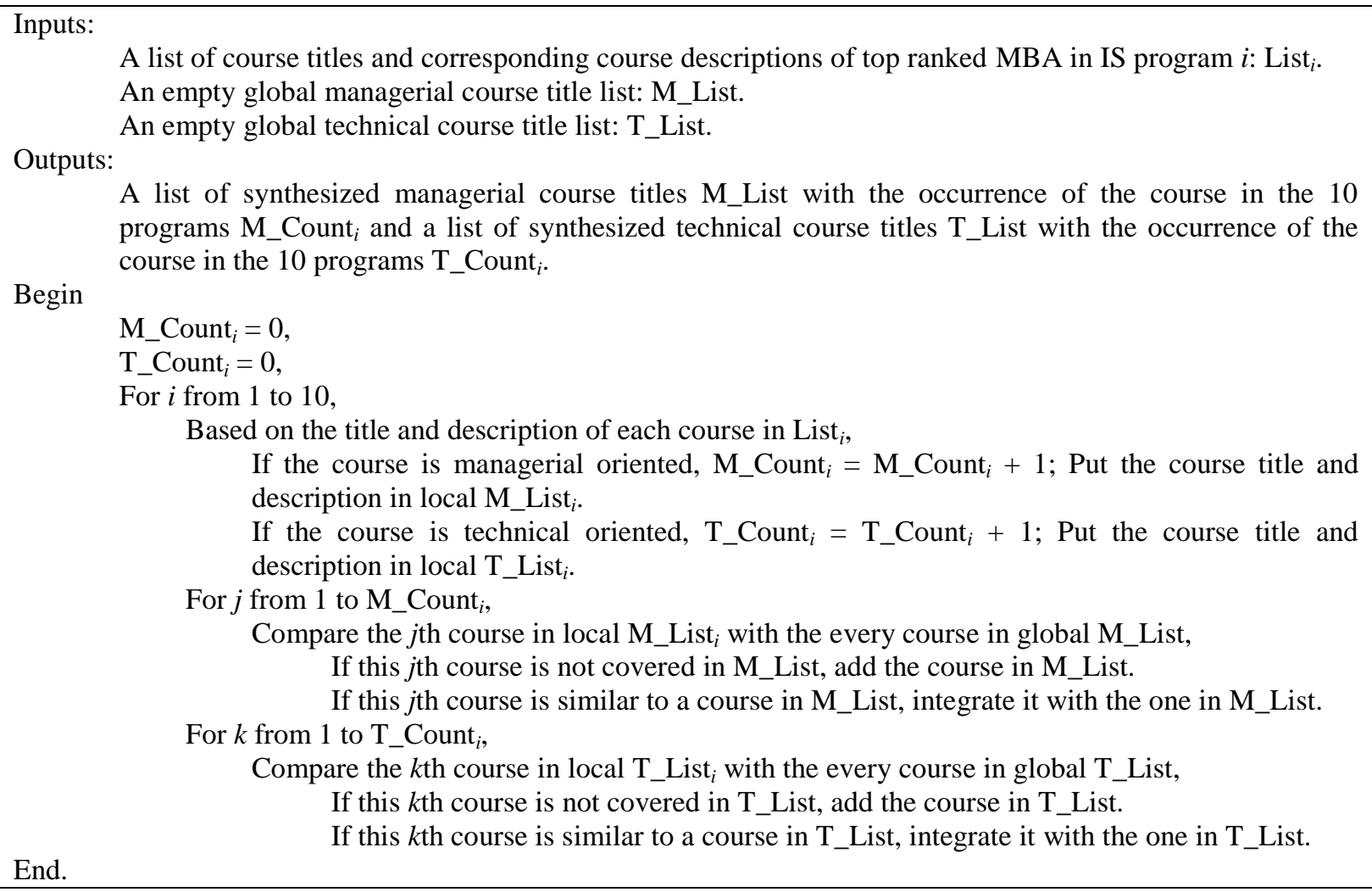

Figure 1. Algorithm for Processing Courses Using Grounded Theory

When integrating a course from each program with the one in the global course list M_List or T_List, a general title is used to represent the course after the synthesis and integration. For example, an Information Systems Strategy course is synthesized from the following courses offered by six universities: Technology Strategy, Information Systems Strategy, Information Technology Strategy and Services, IT Strategy, Information Technology and Corporate Strategy, and Business Strategy and the Role of IT. 


\section{Issues in Information Systems}

Volume 13, Issue 1, pp. 123-130, 2012

\section{RESULTS}

Following the grounded theory approach by which we synthesized the collected courses from the two areas of focus, 54 unique managerially oriented courses were identified and 42 unique technically oriented courses were found. A program is managerially oriented if the number of managerial courses is higher than the number of technical courses and vice versa. Table 2 shows the number of courses processed and the percentage of courses in the two major areas of focus. As a result, the Massachusetts Institute of Technology, the University of Minnesota, the University of Texas at Austin, the University of Maryland, the University of Pennsylvania, Stanford University, and New York University are managerially oriented. The rest of the three universities, Carnegie Mellon University, the University of Arizona, and Georgia State University, offer technically oriented MBA in IS programs. In general, the University of Texas at Austin has the best coverage in IS programs since it has a total 38 courses. The University of Pennsylvania has the strongest emphasis on the managerial part of IS (83.33\%), while Carnegie Mellon University has the strongest focus on IS technology $(66.67 \%)$.

Table 2. Statistics of Courses Offered by Top 10 MBA in IS Programs

\begin{tabular}{|l|c|c|c|c|c|}
\hline \multirow{2}{*}{ University Name and Rank } & \multicolumn{2}{|c|}{ Managerially Oriented } & Technically Oriented & \multirow{2}{*}{ Total } \\
\cline { 2 - 5 } & Number & Percentage & Number & Percentage & \\
\hline 01-Massachusetts Institute of Technology (Sloan) & 12 & $75.00 \%$ & 4 & $25.00 \%$ & 16 \\
\hline 02-Carnegie Mellon University (Tepper) & 5 & $33.33 \%$ & 10 & $66.67 \%$ & 15 \\
\hline 03-University of Minnesota (Carlson) & 6 & $54.55 \%$ & 5 & $45.45 \%$ & 11 \\
\hline 04-University of Texas at Austin (McCombs) & 24 & $63.16 \%$ & 14 & $36.84 \%$ & 38 \\
\hline 05-University of Arizona (Eller) & 11 & $47.83 \%$ & 12 & $52.17 \%$ & 23 \\
\hline 06-University of Maryland (Smith) & 5 & $55.56 \%$ & 4 & $44.44 \%$ & 9 \\
\hline 07-University of Pennsylvania (Wharton) & 10 & $83.33 \%$ & 2 & $16.67 \%$ & 12 \\
\hline 08-Stanford University & 7 & $53.85 \%$ & 6 & $46.15 \%$ & 13 \\
\hline 09-Georgia State University (Robinson) & 10 & $41.67 \%$ & 14 & $58.33 \%$ & 24 \\
\hline 10-New York University (Stern) & 6 & $75.00 \%$ & 2 & $25.00 \%$ & 8 \\
\hline Total Courses & 96 & $56.80 \%$ & 73 & $43.20 \%$ & 169 \\
\hline Total Unique Courses & 54 & $56.25 \%$ & 42 & $43.75 \%$ & 96 \\
\hline
\end{tabular}

Moreover, Table 3 lists the most commonly covered managerial courses and technical courses offered by the top 10 MBA programs. Only the courses offered by at least two programs are included. Based on the results, we find that Information Systems Strategy and Supply Chain Management are the most popular managerial courses, offered by six programs. Similarly, Data Mining is the most commonly offered technical course, provided by six programs.

Table 3. Most Common Courses Offered by Top 10 MBA in IS Programs

\begin{tabular}{|l|c|l|c|}
\hline \multicolumn{2}{|c|}{ Managerially Oriented Courses } & \multicolumn{2}{c|}{ Technically Oriented Courses } \\
\hline Course Title & $\begin{array}{c}\text { Number of } \\
\text { Programs } \\
\text { Offering } \\
\text { the Course }\end{array}$ & \multicolumn{1}{|c|}{ Course Title } & $\begin{array}{c}\text { Number of } \\
\text { Programs } \\
\text { Offering } \\
\text { the Course }\end{array}$ \\
\hline Information Systems Strategy & 6 & Data Mining & 6 \\
\hline Supply Chain Management & 6 & $\begin{array}{l}\text { Business Telecommunications and } \\
\text { Networks }\end{array}$ & 5 \\
\hline Business Process Innovation & 5 & Database Management Systems & 5 \\
\hline $\begin{array}{l}\text { Information Technology Project } \\
\text { Management }\end{array}$ & 4 & Decision Support Systems & 4 \\
\hline Management of Information Systems & 4 & Knowledge Management & 4 \\
\hline $\begin{array}{l}\text { Security and Privacy of Information and } \\
\text { Information Systems }\end{array}$ & 4 & Web Application Development & 4 \\
\hline Enterprise Resource Planning Systems & 3 & $\begin{array}{l}\text { Information Systems Design and } \\
\text { Implementation }\end{array}$ & 3 \\
\hline Global Systems Sourcing & 3 & Digital Evolution: Managing Web 3.0 & 2 \\
\hline
\end{tabular}




\section{Issues in Information Systems}

Volume 13, Issue 1, pp. 123-130, 2012

\begin{tabular}{|l|c|l|c|}
\hline Management of Information Technology & 3 & Enterprise Architecture & 2 \\
\hline $\begin{array}{l}\text { Technology Transfer: Theory and } \\
\text { Practice }\end{array}$ & 3 & $\begin{array}{l}\text { Financial Information Systems and } \\
\text { Technology }\end{array}$ & 2 \\
\hline Business Foundations for IT & 2 & Information Technology Essentials & 2 \\
\hline $\begin{array}{l}\text { Global Information Systems: Strategic, } \\
\text { Technical, and Organizational } \\
\text { Perspectives }\end{array}$ & 2 & Systems Development & 2 \\
\hline Innovation, Problem Solving and Design & 2 & Systems Integration & 2 \\
\hline Introduction to Electronic Commerce & 2 & Wireless Networks & 2 \\
\hline $\begin{array}{l}\text { Leadership Lab: Leading Sustainable } \\
\text { Systems }\end{array}$ & 2 & Digital Evolution: Managing Web 3.0 & 2 \\
\hline Management of Technology & 2 & Enterprise Architecture & 2 \\
\hline Managerial Decision Making & 2 & $\begin{array}{l}\text { Financial Information Systems and } \\
\text { Technology }\end{array}$ & 2 \\
\hline Managing Disruptive Innovations & 2 & - & - \\
\hline Managing for Quality Improvement & 2 & - & - \\
\hline
\end{tabular}

\section{CONCLUSIONS AND FUTURE DIRECTIONS}

Following grounded theory, we analyzed the top $10 \mathrm{MBA}$ in IS programs. In total, 169 courses were collected from the programs and classified into managerially oriented and technically oriented groups. In sum, 54 unique managerial courses were found and 42 unique technical courses were identified. Information Systems Strategy and Supply Chain Management are the most commonly covered managerial courses, while Data Mining is the most commonly offered technical course. Based on the coverage of courses, the University of Texas at Austin stands out among the 10 programs, providing 38 IS courses.

Seven out of the top $10 \mathrm{MBA}$ in IS programs are managerially oriented, while only three programs pay more attention to the technical side of information systems. The University of Pennsylvania has the strongest emphasis on the managerial part of IS, providing 10 managerial IS courses ( $83.33 \%$ of 12 courses). Carnegie Mellon University is the school with the strongest focus on IS technology (66.67\% of 15 courses).

In addition, a school's MBA in IS program should strengthen the technical side of business administration. It is no surprise that the top two programs ranked by U.S. News and World Report [19] are well-known institutions with brand names highly associated with technology. However, it is interesting to see that the Massachusetts Institute of Technology (top ranked) emphasizes more the managerial part of information systems (75\% of available 16 courses). Although Carnegie Mellon University claims to offer cross-campus technical academic experience through its MBA program from the Computer Science and Information Networking disciplines [1], its MBA program still has the strongest focus on technology by offering $66.67 \%$ of technically oriented courses out of 15 available electives. As suggested by Topi et al. [13] for graduate programs in IS, we find that Stanford University and Carnegie Mellon University have included biotechnology into their MBA in IS programs.

This study reports the available courses found on a university's program website or its graduate catalog. A website or catalog can show only the potential of taking the courses. Thus, this uncertainty of course offerings might limit their use for analysis. The current study opens up a variety of future directions. The current study can be further extended to rank the top programs based on the details of courses and other aspects of the programs. The results can be compared with the well known U.S. News and World Report graduate school ranking. Also, most top MBA programs are ACCSB (http://www.accsb.edu) accredited. The analysis can be extended to include a comparison with IS/computer programs accredited by ABET (http://www.abet.org). Another future study can focus on the ontology design of IS development [7] that includes the semantic structure of the IS problems. 


\section{Issues in Information Systems}

Volume 13, Issue 1, pp. 123-130, 2012

\section{REFERENCES}

1. Carnegie Mellon University (2012a). "Concentrations: Tepper School of Business at Carnegie Mellon", Retrieved from http://www.tepper.cmu.edu/mba/mba-programs-coursework/generalmanagement/concentrations/index.aspx\#informationsystems

2. Carnegie Mellon University (2012b). "Technology Leadership MBA Track: Tepper School of Business at Carnegie Mellon", Retrieved from http://www.tepper.cmu.edu/mba/mba-programs-coursework/mbatracks/technology-leadership/index.aspx

3. Georgia State University (2012). "Concentrations - Department of Computer Information “, Retrieved from http://robinson.gsu.edu/cis/mba/concentrations.html

4. Glaser, B.G., and Strauss, A. (1967). The Discovery of Grounded Theory: Strategies for Qualitative Research. Aldined Publishing Co., Chicago, IL.

5. Gorgone, J.T., Gray, P., Stohr, E.A., Valacich, J.S., Wigand R.T. (2006). MSIS 2006: Model Curriculum and Guidelines for Graduate Degree Programs in Information Systems. ACM SIGCSE Bulletin, 38(2), 121-196.

6. Harder J.T. and Harper, J.S. (2003). A Framework For MIS Student Outcome Assessment And Program Review. The Review of Business Information Systems, 7(4), 83-92.

7. Kroeze, J.H., Lotriet, H.H., Mavetera, N., Pfaff, M.S., Postma, D.J.R., Sewchurran, K., Topi, H. (2011). ECIS 2010 Panel Report: Humanities-Enriched Information Systems. Communication of the Association for Information Systems, 28, 373-392.

8. Mead, N.R., Allen, J.H., Ardis, M., Hilburn, T.B., Kornecki, A.J., Linger, R., McDonald, J. (2010). Development of a Master of Software Assurance Reference Curriculum. International Journal of Secure Software Engineering. 1(4), 18-34.

9. New York University (2012). "NYU Stern Full-time MBA Management of Technology and Operations", Retrieved form http://www.stern.nyu.edu/programs-admissions/full-time-mba/academics/specializations/ management-of-technology-and-operations/index.htm

10. Pyster, A. (Ed.). (2009). Graduate Software Engineering 2009 (Gswe2009) Curriculum Guidelines for Graduate Degree Programs in Software Engineering, Version 1.0. Hoboken, NJ: Stevens Institute of Technology.

11. Shoemaker, D., Ulferts, G., Drommi, A. (2005). A Prototype Curriculum for the Study of Software Management. The Review of Business Information Systems, 9(2), 35-44.

12. Topi, H., Valacich, J.S., Wright, R.T., Kaiser, K., Nunamaker, J.F., Sipior, J.C., de Vreede, G.-J. (2010). IS 2010: Curriculum Guidelines for Undergraduate Degree Programs in Information Systems. Communication of the Association for Information Systems, 26, 359-428.

13. Topi, H., Helfert, M., Ramesh, V., Wigand, R.T., Wright, R.T. (2011). Future of Master's Level Education in Information Systems. Communication of the Association for Information Systems, 28, 437-452.

14. University of Arizona (2012). "Concentration and Focus Area: The Eller MBA Curriculum", Retrieved from http://ellermba.arizona.edu/fulltime/curriculum/curriculum/concentrations.asp\#mis

15. University of Maryland (2012) "The Smith MBA - Electives", Retrieved from http://www.rhsmith.umd.edu/mba/curriculum/electives.aspx

16. University of Minnesota (2012). "Information Systems Emphasis - MBA Program - Carlson School of Management", Retrieved from http://www.csom.umn.edu/MBA/emphasis/information-systems.html\#tab1

17. University of Pennsylvania (2012) "The Wharton MBA Program | Majors", Retrieved from http://www.wharton.upenn.edu/mba/academics/majors.cfm

18. University of Texas at Austin (2012). "Information Management", Retrieved from http://www.mccombs.utexas.edu/MBA/Full-Time/ProgramInformation/Curriculum/ /link.aspx?_id=84E2094492EA429AA255728F27E5EEE5\&_z=z

19. U.S. News and World Report (2012a). Best Graduate Schools 2013. U.S. News and World Report.

20. U.S. News and World Report (2012b). "Best Information Systems Programs", Retrieved from http://gradschools.usnews.rankingsandreviews.com/best-graduate-schools/top-business-schools/information-systemsrankings 